Peeling off musculoskeletal labels: sticks and stones may break my bones, but diagnostic labels can hamstring me forever

\author{
Daniel Jonah Friedman (1) , ${ }^{1}$ Louise Tulloh, ${ }^{2}$ Karim M Khan (ㄱ) 3,4
}

Overdiagnosis in healthcare is a problem. A big one. Clinicians are skilled at labelling people in ways that do not necessarily benefit them. Too often we create harms from unnecessary labels and subsequent treatments that waste healthcare resources. Learning from Preventing Overdiagnosis conferences, Choosing Wisely ${ }^{1}$, the BMJ's Too Much Medicine ${ }^{2}$ and JAMA's Less is More $^{3}$ campaigns, we opine that sport and exercise medicine is not exempt from overlabelling.

\section{THAT WHICH WE CALL A LABEL}

For clinicians and researchers, a single label captures a textbook chapter's worth of information. It helps characterise and organise peoples' conditions within definable boundaries. Just as a patient wants to find a cause for their woes, we clinicians pride ourselves on identifying it.

If a label can legitimise an individual's experience, provide identity, and enable external support through access to services and insurance, what's not to love? Why don't we clinicians quickly and indelibly punch the label into a patient's electronic medical record?

There is a dark side to the face of the diagnostic label. A label implies that the clinician knows the specific tissue pathology that is causing pain or dysfunction. In sport and exercise medicine, accurate tissue or pathoanatomical ('structural') diagnosis is often impossible; when a person presents with low back or knee pain, special tests and imaging do not necessarily reveal the cause.

What about 'mechanistic' labels? Is disc disease 'degenerative'? Is a meniscus 'torn'? These labels may catalyse a looping

\footnotetext{
${ }^{1}$ Alfred Health, Melbourne, Victoria, Australia ${ }^{2}$ North Sydney Sports Medicine Centre, St Leonards, New South Wales, Australia

${ }^{3}$ Family Practice and Kinesiology, The University of British Columbia, Vancouver, British Columbia, Canada ${ }^{4}$ Canadian Institutes of Health Research-Institute of Musculoskeletal Health, Vancouver, Ontario, Canada
}

Correspondence to Dr Daniel Jonah Friedman, Alfred Health, Melbourne VIC 3004, Australia; ddfriedman@gmail.com effect $^{4}$ of catastrophisation, anxiety and fear of movement. Each person interprets each label differently-many labels have negative connotations. If a diagnostic MRI in a person with knee pain describes a meniscal tear, this may nudge the patient (and clinician) to prioritise options such as arthroscopic surgery ${ }^{5}$ that are not indicated as first-line therapy.

\section{SO WHEN SHOULD CLINICIANS LABEL?}

If the clinical presentation is acute, it makes sense to label it. A traumatic fracture from a collision, or a hamstring torn mid-sprint, deserve confident labels. The structure affected and the mechanism are clear. Concealing or obfuscating diagnosis to reduce anxiety is paternalistic. But even in these seemingly straightforward circumstances of acute, obvious injury, clinicians' language profoundly affects patients' attitude towards the injury. For example, a patient may consider a 'broken bone' to be significantly worse than a 'crack in the bone'. 6

But what about chronic conditions? Many labels that are spouted in sport and exercise medicine reflect normal findings in asymptomatic individuals. When imaging reveals incidental structural changes such as joint space loss or subchondral sclerosis that does not relate to pain and dysfunction, what is the benefit of a label that may harm the healthy? When clinicians then emphasise osteoarthritic 'wear and tear', are we surprised that people avoid movement and anticipate a poor prognosis?

\section{STRATEGIC LABELLING}

How can we navigate our current nosological framework to prevent overdiagnosis and subsequent harms?

1. Embrace the non-specific regional label. Expert load management and contemporary rehabilitation practices have taught clinicians to not merely rehabilitate a specific island of injured tissue; instead expert clinicians rehabilitate the entire kinetic chain/region. We recommend labelling to reflect regional load and movement impairments. Labels such as non-specific low back pain or shoulder-related pain ${ }^{7}$ reflect multifactorial aetiology that can help clinicians identify best management. A label should be a constructive and dynamic guide that helps validate an individual's experience. It is not an endpoint.

2. De-label if low risk. If red flags have been excluded, and there is reason to believe a label causes more harm than good and/or does not change management, could we dare to not label at all or peel off an inappropriate label? Could we resist the temptation to attach a diagnostic label to transient indeterminate symptoms? We clinicians may help individuals by explaining the limited and likely negative value of repeat investigations to find a label.

3. If clinicians' electronic medical record demands a label, those clinicians must explain to the patient what the label means-and doesn't mean. A diagnostic code does not reflect the continuum or biopsychosocial spheres of an individual's experience. The clinician must: (1) explain age-appropriate and expected findings, and (2) address the patient's negative beliefs and coping responses that may lead to progressive pain and impairment.

Academic journals, medical associations and specialist colleges are ideally placed to provide authoritative clinician and patient education. They should also model best practice for patient-centred communication through various media.

4. Always remember that words can hurt. ${ }^{8}$ Instead of using concrete degenerative terms such as 'wear and tear' in overuse conditions, we clinicians can utilise terms such as 'overloaded', 'irritated'

Box 1 Five questions for clinicians to ask themselves before they label

1. Is it an acute or chronic problem that requires evidence-based treatment?

2. Is my label a specific tissue pathology or structural descriptor that may be unhelpful for the patient's understanding of their symptoms?

3. If I label, will I be encouraging additional potentially costly and harmful investigations or interventions?

4. If I label, will I be helping or impeding recovery?

5. Who is the beneficiary of my words? 
or 'aggravated' that imply load-based management and reflect the dynamic nature of biological systems. This could shift both clinicians' and patients' perspectives so both feel more comfortable choosing active rehabilitation (avoiding unnecessary 'structural' intervention such as surgery).

Just as Choosing Wisely ${ }^{1}$ encourages people to ask their clinician five questions during consultations to promote the right amount of care, we suggest sport and exercise medicine clinicians consider five questions to prevent overlabelling (box 1).

Twitter Daniel Jonah Friedman @ddfriedman, Louise Tulloh @DrLouiseTulloh and Karim M Khan @KarimKhan_IMHA

Contributors DJF was responsible for conception and initial draft of the manuscript. LT and KMK were involved in drafting and critical revision of the manuscript, as well as final approval of the version to be published.

Funding The authors have not declared a specific grant for this research from any funding agency in the public, commercial or not-for-profit sectors.

Competing interests DJF and LT are associate editors for BJSM. KMK is the former editor in chief of BJSM.

Patient consent for publication Not required.

Provenance and peer review Not commissioned; externally peer reviewed.

\section{(2)}

\section{OPEN ACCESS}

Open access This is an open access article distributed in accordance with the Creative Commons Attribution Non Commercial (CC BY-NC 4.0) license, which permits others to distribute, remix, adapt, build upon this work non-commercially, and license their derivative works on different terms, provided the original work is properly cited, appropriate credit is given, any changes made indicated, and the use is non-commercial. See: http:// creativecommons.org/licenses/by-nc/4.0/.

(c) Author(s) (or their employer(s)) 2021. Re-use permitted under CC BY-NC. No commercial re-use. See rights and permissions. Published by BMJ.

\section{Check for updates}

To cite Friedman DJ, Tulloh L, Khan KM. Br J Sports Med Epub ahead of print: [please include Day Month Year]. doi:10.1136/bjsports-2021-103998 Accepted 21 April 2021

Br J Sports Med 2021:0:1-2. doi:10.1136/bjsports-2021-103998

\section{ORCID iDs}

Daniel Jonah Friedman http://orcid.org/0000-00026233-1759
Karim M Khan http://orcid.org/0000-0002-9976-0258

\section{REFERENCES}

1 Choosing Wisely Australia. 5 questions to ask your doctor or other healthcare provider before you get any test, treatment, or procedure. Australia. Available: https://www.choosingwisely.org.au/resources/ consumers-and-carers/5questions [Accessed 19 Jan 2021].

2 The BMJ. Too much medicine. Available: https://www. bmj.com/too-much-medicine [Accessed 19 Jan 2021].

3 JAMA Network. Less is more. Available: https:// jamanetwork.com/collections/44045/less-is-more [Accessed 19 Jan 2021].

4 Hacking I. The looping effects of human kinds. In: Sperber D, Premack D, Premack AJ, eds. Causal cognition: a multidisciplinary debate. Oxford University Press, 1996: 351-94.

5 Sihvonen R, Paavola M, Malmivaara A, et al. Arthroscopic partial meniscectomy for a degenerative meniscus tear: a 5 year follow-up of the placebosurgery controlled fidelity (Finnish degenerative meniscus lesion study) trial. $\mathrm{Br}$ I Sports Med 2020;54:1332-9

6 Azam N, Harrison M. Patients' perspectives on injuries. Emerg Med J 2011;28:601-3.

7 Cools AM, Michener LA. Shoulder pain: can one label satisfy everyone and everything? Br I Sports Med 2017:51:416-7.

8 Nickel B, Barratt A, Copp T, et al. Words do matter: a systematic review on how different terminology for the same condition influences management preferences. BMJ Open 2017;7:e014129. 